\title{
Applying Wordflow Technique to Increase Cadets' English Vocabulary
}

\author{
Muhammad Sapril Siregar, Nanda Afra Kusturi, Maulina Tanjung \\ Malahayati Merchant Marine Polytechnic \\ Jl.Laksamana Malahayati KM.19 Gampong Durung kec. Mesjid Raya, 0651-33606/0651-33609 \\ e-mail: msaprilsiregar@poltekpelaceh.ac.id
}

\begin{abstract}
This research aimed to know Wordflow technique can increase cadets' vocabulary and the obstacles in applying Wordflow technique in memorizing English vocabulary. The research was conducted at Malahayati Merchant Marine Polytechnic in Aceh Besar. The participants of the research were 30 cadets nautical Alpha Diploma III. The research addressed tests, questionnaire and observation to collect the data. The result of this research showed that Wordflow Technique increased cadets' in memorizing English vocabulary. It was proved by the data from pretest and posttest score; it was shown that the cadets mean score from pre-test was 65 and was significant increased to post-test was 70,5. In addition, the obstacles when applying Wordflow technique were lack of fair group, time, noisy. To sum up, the cadets were enjoyed, interested and motivated the cadets to memorize vocabulary using Wordflow.
\end{abstract}

Keywords: Teaching Vocabulary, Wordflow Technique, Cadets' Obstacle, Memorize English Vocabulary.

\section{Introduction}

Vocabulary is very important in learning English because it is the key to communicate with other people. If we have limited vocabulary, we cannot communicate easily with people and cannot give our opinion and build the social life. Reference [1] explained Vocabulary is the words to communicate effectively in speaking (expressive vocabulary) and words in listening (receptive vocabulary). The success in mastering a language is determined by the amount of the vocabulary one has learned. The cadets having a good command of vocabulary will be more confident and it is easy for them to convey ideas in a conversation. As a result, they may not find any difficulties in explaining their ideas. That is why mastering vocabulary is very important.

Vocabulary mastery includes knowing the words and their meanings as well as finding the synonym. In learning process, vocabulary also has an important role in mastering speaking, listening, writing and reading. For example, without knowing many vocabulary the cadets are difficult to express their idea in writing. In term of learning English listening skill, when the cadets do not have many words, they feel unfamiliar with those words, and cannot catch the words which affect to their understanding of the conversation. This situation also happens in learning speaking skill. If we do not have many vocabulary we cannot produce many sentences, as a result we cannot communicate with others. In reading English text, having many vocabulary helps to understand the content of the text and have more information about the subject matter. Reference [2] says

This paper is presented in The $4^{\text {th }}$ International Conference on Maritime Education and Training

October $8^{\text {th }}$, 2020, Makassar, Indonesia 
vocabulary is the important basic foundation for mastering English skills including writing, reading, listening and speaking.

In short, it is almost impossible to learn a language without words. Thus, vocabulary is the key in studying English as foreign language, cadets may feel bored to study vocabulary because in their mind they have to memorize all the English words with pressure. As a result, the cadets may feel uninterested in memorizing vocabulary. That situation happens at Malahayati Merchant marine Polytechnic. When teaching in that school, the cadets have some problems in learning English, especially in memorizing vocabulary. In addition, they also have a lot of activities at the college. They tend to be overthinking and get stress. Thus, to motivate them memorizing vocabulary using various techniques in teaching vocabulary is necessary.

There are many strategies or techniques that can be applied by both teachers and cadets in English teaching-learning integrated with mastering vocabulary. One of them is cooperative learning method by using Wordflow technique. Wordflow is one of interesting technique that can be used in teaching vocabulary because this technique uses different pictures for each group like a game. Based on the reason above, applying this technique is the same as a playing a game which could prevent the cadets' boredom of memorizing vocabulary.

According to reference [3] relating the importance of vocab in four skills, if you spend most of your time in studying grammar, your English will not improve very much. Reference [3] it is almost impossible to learn a language without words even communication between human beings is based on words.

To solve the problem, the cadets must have the target of the total number of vocabulary mastery to make the learning process easy. To encourage the cadets memorize the vocabulary the lecturers have to use various strategies. One of them was by applying Wordflow technique. In brief, the writers wants to see the effectiveness of applying the Wordflow technique to increase the cadets' vocabulary in memorizing English vocabulary.

\section{Research Method}

\subsection{Participants}

Participants of this research was all of nautical Alpha DP III the second year cadets at Malahayati Merchant Marine pholytechnic. The class had around 30 cadets. The writers conducted an experimental teaching at Malahayati Merchant Marine Polytechnic.

\subsection{Research Design}

In this research, the writers used mixed methods, combination qualitative and quantitative approached to answer the research questions. A quantitative method is used to answer first research questions about cadets' improvement using Wordflow technique. Reference [4] says quantitative research requires the reduction of phenomena to numerical values in order to carry out the statistical analysis. Meanwhile, a qualitative method is used to answer the second research question about the cadets' obstacles using Wordflow technique. The writers used pre-experimental method, because there is only one class for teaching experiment. One Group Pre-test- Post-test is one of the designs of preexperimental method that has one group of experiment without using control group, to know the significant is by comparing the score of pre-test and post-test reference [5].

\subsection{Technique of Data Collection}

The writers did the experimental teaching in this research. The writers used some techniques for collecting data.

This paper is presented in The $4^{\text {th }}$ International Conference on Maritime Education and Training 
a. Test

Reference [6] stated test is a tool or procedure to know or measure something in condition, by the manner and arrangement that has been decided. The writers provided pre-test and post-test. The writers held a pre-test before the experimental teaching was started. Pre-test was used to see the cadets respond about their prior knowledge and to see how their teaching learning process happen, then the writers held post-test after applying Wordflow in English teaching learning process.

b. Questionnaire

Questionnaire was a number of written questions used to get information from respondent. As reference [7] stated questionnaire is one of the methods to get the data indirectly from the respondent. The questionnaire was given in the last meeting in order to investigate cadets' perception about applying Wordflow in English teaching learning and also to find out the effect of Wordflow on improving their vocabulary in English teaching learning process.

c. Observation

Reference [8] stated observation is a way to collect data which is done by using an observing and noting systematically to the events which become the target observation. During teaching learning process, the writers who was also the teacher of the class, observed the cadets using Wordflow technique from the beginning of each class and took notes on everything that happen during the learning process, including the problems or difficulties that may appear. Observations also help the writers to directly see cadets' improvement of English skill.

\subsection{The Process of Data Analysis}

The data collected through test and questionnaire will be analyzed in the following ways:

\section{Test}

Data from test will be analyzed by using the statistical calculation which consists of mean and t-test, with the steps below:

a. The first step is the writers tabulates the scores of pre-test and post-test.

b. Second, the writers calculates the mean score from post-test.

To calculate the mean in central tendency, the following formula is used:

$$
X=\frac{\sum \mathrm{x}_{\mathrm{i}}}{\mathrm{n}}
$$

Where:

$X=$ Mean

$\Sigma \mathrm{x}_{\mathrm{i}}=$ Total of the test

$n=$ Total of cadets

2. Analyzing questionnaire

Data from questionnaire will be analyzed by finding the percentage each statement for each answer option, by using the following formula:

$\mathrm{P}=$ percentage

$\mathrm{f}=$ the number of respondents who choose certain option

$\mathrm{n}=$ the number of all respondents

This paper is presented in The $4^{\text {th }}$ International Conference on Maritime Education and Training 


\section{Analyzing observation data}

The writers used analytic field notes. Analyzing field notes data was a process that occurs over time, beginning at the moment the writers entered the field and continued as interactions were happening in the field; and field notes should be written as soon as possible after leaving the field site, immediately if possible. Even though we may not think so when we are participating and observing, we are all very likely to forget important details unless we write them down very quickly. Since this may be very time-consuming, the writers should plan to leave a block of time for writing just after leaving the research [9] have developed a list of what should be included in all field notes:

1. Date, time, and place of observation

2. Specific facts, numbers, details of what happens at the site

3. Sensory impressions: sights, sounds, textures, smells, taste

4. Personal responses to the fact of recording field notes

5. Specific words, phrases, summaries of conversations, and insider language

6. Questions about people or behaviors at the site for future investigation

7. Page numbers to help keep observations in order

After collecting the data, the writers used qualitative research data by identifying pattern. Reference [10] in qualitative research, qualitative research can help researchers to access the thoughts and feelings of research participants, which can enable development of an understanding of the meaning that people ascribe to their experiences. The writers explore the shape and scope of the emerging categories and investigate potential connections among categories. As more data was analysis, the writers also consider aspects such as the range of variation within individual categories. These processes can assist in the procedure of adapting and finalizing the data system, with the goal of closely reflecting and repsenting the data reference [11].

\section{Results and Analysis}

\subsection{The Analysis of test}

Following the experimental teaching, the writers analyzed the data by using a statistical calculation. As mention in the previous chapter, the analysis was used to find out whether there was significant different between the pretest and posttest result after the treatment was given. Thus, the writers could compare the cadets' ability before and after classroom treatment of applying Wordflow technique. By comparing the result of the test before and after treatment we can see whether the cadets' ability is improved or not.

In analayzing the test result, the writers started with arranging the cadets pretest and posttest score from the lowest score to the highest score. Then, it needed to make table of frequency distribution. According to [13] there are four steps that must be followed in analyzing the table of frequency distribution such as: determining range, the interval class, the length of the interval class, and the lowest score of the first interval. To make it brief, the cadets' score of vocabulary pretest and posttest is presented in the table below:

Table 4.1: The Cadets' Scores of Vocabulary Pre-test and Post-test

\begin{tabular}{cccc}
\hline No & Inisials' Name & Pre-Test & Post-test \\
\hline 1 & AK & 75 & 85 \\
2 & AM & 70 & 77 \\
3 & ARD & 60 & 70 \\
4 & AS & 55 & 63 \\
5 & AM & 60 & 72 \\
6 & AW & 50 & 65
\end{tabular}

This paper is presented in The $4^{\text {th }}$ International Conference on Maritime Education and Training 194 


\begin{tabular}{cccc}
7 & AZ & 60 & 70 \\
8 & DIR & 55 & 70 \\
9 & DP & 55 & 73 \\
10 & AKG & 73 & 80 \\
11 & AAP & 75 & 85 \\
12 & DA & 75 & 85 \\
13 & FA & 65 & 73 \\
14 & FJ & 68 & 70 \\
15 & FAA & 65 & 75 \\
16 & FSN & 63 & 60 \\
17 & FH & 60 & 70 \\
18 & FD & 50 & 50 \\
19 & FR & 60 & 73 \\
20 & FRB & 70 & 75 \\
21 & IA & 70 & 75 \\
22 & JW & 60 & 65 \\
23 & NA & & 75 \\
24 & NW & 60 & 65 \\
25 & NAK & 65 & 73 \\
26 & MA & 70 & 65 \\
27 & MD & 65 & 70 \\
28 & SA & 70 & 60 \\
29 & RD & 70 & 80 \\
30 & SR & 60 & 70 \\
\hline Total & 30 & 1909 & 2139 \\
\hline
\end{tabular}

The lowest up to the highest score of cadets' vocabulary pretest \&posttest can be arranged as follows :

Pre-test

$\begin{array}{lllllllllll}50 & 50 & 55 & 55 & 55 & 55 & 60 & 60 & 60 & 60 & 60 \\ 60 & 60 & 63 & 65 & 65 & 65 & 65 & 65 & 68 & 68 & 70 \\ 70 & 70 & 70 & 70 & 73 & 75 & 75 & 75 & & & \end{array}$

Post-test

$\begin{array}{lllllllllll}50 & 60 & 60 & 63 & 65 & 65 & 65 & 65 & 70 & 70 & 70 \\ 70 & 70 & 70 & 70 & 72 & 73 & 73 & 73 & 73 & 75 & 75 \\ 75 & 75 & 77 & 80 & 80 & 85 & 85 & 85 & & & \end{array}$

To determine the range of the class, the highest score was minus the lowest score, the formula was below:

$$
\mathrm{R}=\mathrm{H}-\mathrm{L}
$$

Where:

$$
\begin{aligned}
& \mathrm{R}=\text { Range of the Class } \\
& \mathrm{H}=\text { The Highest Score } \\
& \mathrm{L}=\text { The Lowest Score }
\end{aligned}
$$

The formula of interval class was:

Where:

$$
K=1+(3,3) \log n
$$

$$
\begin{aligned}
& \mathrm{K}=\text { Interval Class } \\
& \mathrm{n}=\text { Amount of Sample }
\end{aligned}
$$

After that, to determine the length of the class, the formula was: 
Where:

$$
\mathrm{P}=\mathrm{R} / \mathrm{K}
$$

$\mathrm{P}=$ Length of the Class

$\mathrm{R}=$ Range of the Class

$\mathrm{K}=$ Interval Class

1. Pre-test

Based on the pretest, the highest score of the pretest was 75 and the lowest score was 50. To determine the range score, the formula was:

$$
\begin{aligned}
& \mathrm{R}=\mathrm{H}-\mathrm{L} \\
& \mathrm{R}=75-50 \\
& \mathrm{R}=25
\end{aligned}
$$

The next step was identified the amount of interval class by using the formula below.

$$
\begin{aligned}
& \mathrm{K}=1+(3,3) \log \mathrm{n} \\
& \mathrm{K}=1+(3,3) \log 30 \\
& \mathrm{~K}=1+(3,3) 1,47 \\
& \mathrm{~K}=1+4,851 \\
& \mathrm{~K}=5,851(\text { chosen } 6) \\
& \mathrm{K}=6
\end{aligned}
$$

After finding the amount of the interval class, the length of the interval class was found out by using:

$$
\begin{aligned}
& \mathrm{P}=\mathrm{R} / \mathrm{K} \\
& \mathrm{P}=25 / 6 \\
& \mathrm{P}=4,1666 \\
& \mathrm{P}=4 \text { or } 5
\end{aligned}
$$

The last step was substituting the scores into the frequency distribution table as follow:

Table 4.2: The Frequency Distribution Table of Student's Pretest Score

\begin{tabular}{ccccc}
\hline No & Interval's Class & Fi & Xi & FiXi \\
\hline 1 & $50-55$ & 6 & 52,5 & 315 \\
2 & $56-61$ & 7 & 58,5 & 409,5 \\
3 & $62-67$ & 6 & 64,5 & 387 \\
4 & $68-73$ & 8 & 70,5 & 564 \\
5 & $74-79$ & 3 & 76,5 & 274,5 \\
\hline & $\sum \mathrm{fi}=30$ & $\sum \mathrm{Xi}=322,5$ & $\sum \mathrm{fiXi}=1950$ \\
\hline
\end{tabular}

Where:

$\mathrm{Fi}=$ Frequency

$\mathrm{Xi}=$ Middle Score of Interval Class

Fixi $=$ The Amount of The Multiplication between Frequency and Middle

Interval

The mean score of pretest was found out by using the formula:

$$
\begin{gathered}
X=\frac{\sum f i X i}{\sum f i} \\
X=\frac{1950}{30} \\
X=65
\end{gathered}
$$

The mean of pre-test 65. It means that the cadets' ability in learning English vocabulary is in predicate adequate which means the ability of cadets is not high. 


\section{Post-test}

After the calculation of cadets' pretest score, then researcher continued to analyze the posttest score of the cadets. To analyze the posttest score, the writers used the same formula as in pretest. From the arranging data before, it shows that the highest score of posttest was 85 and the lowest score was 60 .

So the range was:

$$
\begin{aligned}
\mathrm{R} & =\mathrm{H}-\mathrm{L} \\
\mathrm{R} & =85-50 \\
& =35
\end{aligned}
$$

The amount of interval class was:

$$
\begin{aligned}
& \mathrm{K}=1+(3,3) \log \mathrm{n} \\
& \mathrm{K}=1+(3,3) \log 30 \\
& \mathrm{~K}=1+(3,3) 1,47 \\
& \mathrm{~K}=1+4,851 \\
& \mathrm{~K}=5,851(\text { chosen } 6) \\
& \mathrm{K}=6
\end{aligned}
$$

Therefore, the length of interval class was:

$$
\begin{aligned}
& \mathrm{P}=\mathrm{R} / \mathrm{K} \\
& \mathrm{P}=35 / 6 \\
& \mathrm{P}=5,833 \text { (chosen } 6) \\
& \mathrm{P}=6
\end{aligned}
$$

After that, the score was tabulated into frequency distribution table below:

Table 4.3: The Frequency Distribution Table of Cadets' Post-test Score

\begin{tabular}{ccccc}
\hline No & Interval's Class & Fi & Xi & FiXi \\
\hline 1 & $50-55$ & 1 & 52,5 & 105 \\
2 & $56-61$ & 2 & 58,5 & 117 \\
3 & $62-67$ & 5 & 64,5 & 451,5 \\
4 & $68-73$ & 12 & 70,5 & 846 \\
5 & $74-79$ & 5 & 76,5 & 153 \\
6 & $80-85$ & 5 & 82,5 & 442,5 \\
\hline & $\sum \mathrm{fi}=30$ & $\sum \mathrm{Xi}=405$ & $\sum \mathrm{fiXi}=2115$ \\
\hline
\end{tabular}

The mean of post-test could be counted by using the formula:

$$
\begin{aligned}
X & =\frac{\sum f i X i}{\sum f i} \\
X & =\frac{2115}{30} \\
X & =70,5
\end{aligned}
$$

So, the mean of the post-test score was 70,5. It means that the cadets' ability in learning vocabulary is in predicate good after the treatment was given. Based on the data, if we compared pre-test and post-test we can see there is an improvement between pretest and posttest, which is pretest was 65 and posttest was 70,5 .

\subsection{The Analysis of Questionnaire}

In this study, questionnaire was constructed to know the cadets' opinions toward the implementation of wordflow technique. It consists of ten questions and in the form of Likert Scale. To analyze the questionnaire data, the writers used the following formula: 
$\mathrm{P}=$ percentage

$$
\mathbf{P}=\mathbf{f} /(\mathbf{n}) \times 100 \%
$$

$\mathrm{f}=$ the number of sample who choose certain option

$\mathrm{n}=$ the number of sample

$100 \%=$ constant value

The detail of questionnaires will be elaborated in the following result tables:

Table 4.4: Cadets' questionnaire toward their responses of using Wordflow to improve their vocabulary

\begin{tabular}{|c|c|c|c|c|c|c|c|}
\hline $\mathrm{N}$ & \multicolumn{2}{|l|}{ Statement } & \multicolumn{4}{|c|}{ Students Responses } & \multirow[t]{2}{*}{ Total } \\
\hline \multirow[t]{3}{*}{1} & \multirow{3}{*}{$\begin{array}{l}\text { My English teacher } \\
\text { used Wordflow } \\
\text { technique in } \\
\text { teaching } \\
\text { vocabulary before. }\end{array}$} & & 1 & 2 & 3 & 4 & \\
\hline & & $f$ & 0 & 0 & 0 & 30 & 30 \\
\hline & & $\%$ & 0 & 0 & 0 & 100,0 & 100 \\
\hline \multirow[t]{2}{*}{2} & \multirow{2}{*}{$\begin{array}{l}\text { I agree if my teacher } \\
\text { applying wordflow } \\
\text { in } \\
\text { teaching vocabulary }\end{array}$} & $f$ & 15 & 14 & 1 & 0 & 30 \\
\hline & & $\%$ & 50,0 & 46,7 & 3,3 & 0 & 100 \\
\hline \multirow[t]{2}{*}{3} & \multirow{2}{*}{$\begin{array}{l}\text { Applying wordflow } \\
\text { increase my } \\
\text { motivation in } \\
\text { learning } \\
\text { English especially } \\
\text { vocabulary }\end{array}$} & $f$ & 10 & 19 & 1 & 0 & 30 \\
\hline & & $\%$ & 33,4 & 63,3 & 3,3 & 0 & 100 \\
\hline \multirow[t]{2}{*}{4} & \multirow{2}{*}{$\begin{array}{l}\text { Studying English } \\
\text { using Wordflow } \\
\text { help } \\
\text { me to improve my } \\
\text { vocabulary }\end{array}$} & $f$ & 9 & 21 & 0 & 0 & 30 \\
\hline & & $\%$ & 30,0 & 70,0 & 0 & 0 & 100 \\
\hline \multirow[t]{2}{*}{5} & \multirow{2}{*}{$\begin{array}{l}\text { I am interested in } \\
\text { studying English } \\
\text { using Wordflow }\end{array}$} & $f$ & 13 & 17 & 0 & 0 & 30 \\
\hline & & $\%$ & 43,3 & 56,7 & 0 & 0 & 100 \\
\hline \multirow[t]{2}{*}{6} & \multirow{2}{*}{$\begin{array}{l}\text { I agree studying } \\
\text { English using } \\
\text { Wordflow improve } \\
\text { my vocabulary }\end{array}$} & $f$ & 12 & 18 & 0 & 0 & 30 \\
\hline & & $\%$ & 40,0 & 60,0 & 0 & 0 & 100 \\
\hline \multirow[t]{2}{*}{7} & \multirow{2}{*}{$\begin{array}{l}\text { I agree if Wordflow } \\
\text { applied when } \\
\text { studying } \\
\text { vocabulary }\end{array}$} & $f$ & 14 & 16 & 0 & 0 & 30 \\
\hline & & $\%$ & 46,7 & 53,3 & 0 & 0 & 100 \\
\hline \multirow[t]{2}{*}{8} & \multirow{2}{*}{$\begin{array}{l}\text { I used to learn } \\
\text { English } \\
\text { before using } \\
\text { Wordflow }\end{array}$} & $f$ & 0 & 0 & 0 & 90 & 30 \\
\hline & & $\%$ & 0 & 0 & 0 & 100,0 & 100 \\
\hline \multirow[t]{2}{*}{9} & \multirow{2}{*}{$\begin{array}{l}\text { I am happy to } \\
\text { studying English } \\
\text { vocabulary using } \\
\text { Wordflow }\end{array}$} & $f$ & 11 & 18 & 1 & 0 & 30 \\
\hline & & $\%$ & 36,7 & 60,0 & 3,3 & 0 & 100 \\
\hline 10 & I get many benefit in & $f$ & 10 & 20 & 0 & 0 & 30 \\
\hline
\end{tabular}

This paper is presented in The $4^{\text {th }}$ International Conference on Maritime Education and Training 198 


\begin{tabular}{|c|l|c|c|c|c|c|c|}
\hline & $\begin{array}{l}\text { studying vocabulary } \\
\text { using Wordflow }\end{array}$ & $\%$ & 33,3 & 66,7 & 0 & 0 & 100 \\
\hline 11 & $\begin{array}{l}\text { Studying English } \\
\text { using wordflow } \\
\text { make } \\
\text { teaching learning } \\
\text { process more } \\
\text { interesting }\end{array}$ & $f$ & 12 & 18 & 0 & 0 & 30 \\
\cline { 2 - 7 } & $\%$ & 40,0 & 60,0 & 0 & 0 & 100 \\
\hline $\begin{array}{l}\text { Studying English } \\
\text { using wordflow } \\
\text { makes } \\
\text { me bored }\end{array}$ & $f$ & 0 & 1 & 3 & 26 & 30 \\
\cline { 2 - 7 } & $\%$ & 0 & 3,34 & 10,0 & 86,6 & 30 \\
\hline
\end{tabular}

Based on the table 4.5 above, the first statement shows that all of the cadets never learn vocabulary using wordflow technique before, it can be seen from their answer that 30 cadets never used the technique and none of the cadets chose agree/strongly agree option.

The second statement shows that 15 of 30 cadets said that they strongly agreed if their teacher applying wordflow technique in learning vocabulary.

The third statement gave information about 10 cadets strongly agreed wordflow technique could motivate the cadets to study English especially vocabulary. Most of cadets (19 cadets) chose agree option, which mean that they believed that wordflow technique can motivate the cadets to study English especially vocabulary.

The fourth statement shows that there were 21 or $70,0 \%$ cadets agree that studying English using wordflow technique could help them to improve their vocabulary.

The fifth statement above shows that almost all of the cadets agreed that they are interested in studying English using Wordflow. There were 13 of them who chose strongly agree, and 17 cadets chose agree. It means that most of cadets agreed that they were interested in using wordflow.

The sixth statement shows that 12 or $40,0 \%$ of 30 cadets said that they strongly agree that wordflow technique could help them to improve their vocabulary. In addition, there were 18 or $60,0 \%$ cadets agreed that wordflow technique could help them to improve their vocabulary.

The seventh statement shows that 14 cadets strongly agreed to apply wordflow in studying vocabulary and other 16 cadets also agreed with it. There were no cadets stated disagreement. It can be concluded that they agreed if wordflow was applied in teaching vocabulary.

The eight statement shows that all of the cadets never learn vocabulary before using wordflow technique, it can be seen from the data that 30 cadets never used the technique and none of the cadets chose agree/strongly agree option.

The ninth statement, from 30 cadets, 11 cadets strongly agreed that they were happy to studying English vocabulary using wordflow. Moreover, 18 cadets agreed with the statement.

The tenth statement shows that 10 or $33,3 \%$ of 30 cadets said that they strongly agree that they got many benefit in studying vocabulary using Wordflow.In addition, there were 20 or $66,7 \%$ cadets agreed that they got many benefit in studying vocabulary using Wordflow.

The eleventh statement above shows that almost all of the cadets agreed that studying English using Wordflow made teaching learning process more interesting. There 
were 12 of them who chose strongly agree, and 18 cadets chose agree. It means that most of cadets agreed that studying English using Wordflow make teaching learning process more interesting.

The last statement shows that 26 cadets strongly disagreed that studying English using wordflow made them feel bored and also 3 cadets stated that disagreed with it. There was one student stated their agreement, but it can be concluded that most of student seem interesting and did not feel bored when studying English vocabulary using Wordflow. So, the result from the data questionnaires above proved that applying Wordflow technique could improve their vocabulary in studying English.

Based on the data from observation and interview, the writers found that most of the cadets feel fun and enjoy the learning process in learning vocabulary using wordflow because the technique is similar as playing the game. Moreover, this technique is new for the cadets so they look enthusiasm in responding to the learning activity. However, the cadets also noted some obstacles in applying wordflow technique. They are:

a. The teacher needs to be wise in grouping cadets so everyone feel comfortable working in group.

b. when applying wordflow technique we have limited time to play because one group consist of four or five cadets, thus to make it fair all the cadets must get turn to make sentences so we need more time to finish the game.

c. There are few cadets who have less vocabulary or vocabulary that her/his know was already taken by her/his friends so the group has to wait and it took time to write a sentence, consequently the group is late to write on the whiteboard.

d. The teacher has to carefully watch the game because sometimes the student will give the paper to the next friend without writing his/her own vocabulary

e. Applying wordflow is similar with a game, thus the class is quite noisy.

\section{Conclusion}

In conclusion, Wordflow can enhanced cadets' vocabulary. It is proved by the posttest score of the class which has a sufficient increased (from 65 to 70,5). Studying English vocabulary by using wordflow technique delivers a positive response from cadets. There are some obstacles when applying wordflow technique such as lack of vocabulary, limited time, lack of vocabulary and noisy. However, although there are some obstacles when applying wordflow but the cadets seem enjoy learning with the technique because it is different technique, fun, and enjoyable.

The cadets do not feel bored and they are very enthusiasm to apply the technique. The writers hoped that Wordflow technique can be used for the English lecturer as a reference in teaching vocabulary, because cadets also need interesting way in memorizing English vocabulary. Thus, they have motivation to memorize the words which later, affect their English skill. In the future, the writers this research can be used as a reference for future research.

\section{References}

[1] Neuman, S. B., \& Dwyer, J. Missing in action: Vocabulary instruction in pre-k. The Reading Teacher. 2009; 62(5), 384-392.

[2] Carter, R. (1987). Vocabulary and second/foreign language teaching. Language Teaching. 1987; 20 (1), 3-16.

[3] Walters, J.M. Teaching the use of context to infer meaning: A longitudinal survey of L1 and L2 vocabulary research. Language Teaching. 2004; 37(4), 243-252.

This paper is presented in The $4^{\text {th }}$ International Conference on Maritime Education and Training 200 
[4] Gelo, O., Braakmann, D., \& Benetka, G. Quantitative and qualitative research: Beyond the debate. Integrative psychological and behavioral science. 2008; 42(3), 266-290.

[5] Fitriyana D. Using Guiding-Question Technique in Teaching English Writing (An Experimental Study at Mtsn 4 Banda Aceh). SPd Thesis. Aceh; Undergraduate UIN: 2018.

[6] Arikunto, S. Dasar-Dasar Evaluasi Pendidikan, Edisi Revisi. Jakarta: Bumi Aksara. 2008: 8.

[7] Syaodih, N. Metode Penelitian Pendidikan. Bandung: PT. Remaja Rosdakarya. 2008: 8.

[8] Sudijono, A. Pengantar Evaluasi Pendidikan. Jakarta: Raja Grafindo Persada. 2005.

[9] Chiseri-Strater, E. FieldWorking: Reading and Writing Research. Universitas Michigan: Prentice Hall. 1997: 73.

[10] Zubin, A. Qualitative Research; Data Collection, Analysis, and Management. CJHP. 2015; 68(3): 226-231

[11] Sudjana, N. Penilaian Hasil Proses Belajar Mengajar. Bandung: PT Remaja Rosdakarya. 2016: 4748. 